\title{
Monitoring of Justice \\ (in Terms of Population Attitude) \\ as an Instrument of Administration
}

\author{
Nikolay G. Stoiko ${ }^{a}$, \\ Larisa A. Novopashina ${ }^{* b}$ and Alexandr A. Petrov \\ ${ }^{a}$ Saint-Petersburg State University \\ 7, 22-ya liniya, Vasilyevsky ostrov, \\ Saint-Petersberg, 199026, Russia \\ ${ }^{b}$ Siberian Federal University \\ 79 Svobodny, Krasnoyarsk, 660041, Russia
}

Received 15.07.2015, received in revised form 11.08.2015, accepted 20.09.2015

The article suggests the model of monitoring of justice, which can be used to evaluate its' effectiveness. The results of the conducted study based on the model show difference in citizens' attitude towards public justice depending on the experience of interaction with a court. The proposed instrument is applicable to the task of monitoring public attitude towards courts' activity and both justice availability and quality.

Keywords: monitoring, administration, available and qualitative justice, criteria and indicators, a model of monitoring of justice.

DOI: 10.17516/1997-1370-2015-8-11-2779-2788.

Research area: psychology.

\section{Introduction}

First of all, we want to thank our colleagues Bogdanova I.S., Brester A.A., Krasnousov S.D., Maltov S.N., Panchenko V.Yu., Patrin K.G., Petrova M.V., Samarnikova N.V., Tarbagaev A.N., Shevchenko I.A., Hasan B.I. for participation in researches, critics and discussion.

The paper presents the idea and some results of our collaborative work, which has been done in framework of Krasnoyarsk Regional Fund of Support for Scientific and Technological Activities $^{1}$ grant project.
The project main idea consists of some provisions:

1. The framework of monitoring is political. So the monitoring has to be analyzed as an instrument of administration.

2. The key interest lies in the political and administerial fields. The case is about authorities' interest which includes a regular updating of information about state of justice. It is an important knowledge to estimate how much the factual situation diverges from an acceptable level of public satisfaction caused by justice execution.

(C) Siberian Federal University. All rights reserved

* Corresponding author E-mail address: nla@ippd.ru 
Particularly, this is about population tolerance towards some drawbacks of justice system.

3. Monitoring as an instrument of administration has to be a mechanism of constant watching over the state of justice, presented in its sustainable, attributional dynamic characteristics. Also appeal to monitoring should give an opportunity to reveal some tendencies of its development.

4. An extraction of attributional features, criteria, indicators and some indexes for its measuring should be carried out in the framework of using two main approaches. One of them is "internal" approach, which is realized from the viewpoint of the professional association. And another one is an "external" ("consumeroriented"), presented from the position of population.

5. An "internal" approach to monitoring must have two focal points, one of which is presented as a legal standard of justice (both national and international) and another one - as a factual standard which consists in the results of self-examination of its own work products.

6. Using an "internal" approach, which is dedicated to the legal standard, it is necessary to take into account some characteristics of the justice in the indexes over the range from «better» to «worse» (that is about modality).

7. Using an "internal" approach, which is dedicated to the factual standard it is important to consider some characteristics of justice in the indexes over the range from "better" to "worse" (that is about modality) and from "harder" to "weaker" (that is about intensity).

8. The "consumer-oriented" approach to monitoring must have three focal points to research. Two of them are special, and one is general. When we are talking about last one we mean electorate's attitude to justice. By other focal points we imply, firstly, the attitude to justice expressed by people who have faced a judicial proceeding and, secondly, an attitude expressed by people who have never had an experience like this.

9. Using a "consumer-oriented" approach it is necessary to take into account characteristics of justice in indexes over the range from "better" to "worse" (that is about modality) and from "harder" to "weaker" (that is about intensity). Also it is important to consider any electorate activity of the population groups and the absence of their professional knowledge and skills.

10. The results of monitoring (an obtained information) must be interpreted to authorities to provide them with an opportunity in making upto-date decisions (during the whole administrative process), which should be approved by human resources in regions. The case is about finding out what modifications of the judicial system are necessary to make, what resources to achieve this goal we already have and how much still have to obtain.

11. The results of monitoring have to reveal a degree of coincidence between some population expectations about the current state of justice and analogical expectations belonged to judges' community.

Herewith we considered, that making administrative decisions, connected to guaranteeing of qualitative and available justice, is based on the only link of administrative connection: "Court President + appropriate body of Justice Department - courts of superior jurisdiction and Justice Department of Supreme Court of the Russian Federation". This is fixed in Clause No. 25 of Federal Law of 22 December 2008 No. 262-FZ “About guaranteeing an access to information about activity of courts in Russian Federation". This is why it was important for us to create the model of monitoring, capable to show population attitude to courts' activity as a main point. 


\section{A model}

During the process of describing the basic criteria, indicators and indexes for "consumeroriented" aspect of monitoring of justice we ascertained that there is a need in another approach to create a system of criteria except the one we used for "internal" approach.

We concentrate our attention on revealing an attitude to justice, expressed by citizens. This is not especially about attitude to any phenomena, which are objectively-existed in sphere of courts' activities. In particular, it is not certainly about any experience of interaction between judicial system and people. It is also about some things that exist in mass consciousness developed under the pressure of sources such as mass media, rumors, information obtained from relatives and acquaintances, etc.

We selected two main groups of respondents:

1) people, who have their own experience of facing the judicial system.

2) people, who have never faced the court's activity.

This way we tried to overcome the quantity limitation of people, who have faced the judicial system before. Besides, we took into account a fidelity of difference between stances of groups, who have faced the judicial system and who have not had such experience.
So, people attitude to courts' activity was the subject of "consumer-oriented" approach to monitoring of justice.

We took a population attitude to justice as a supposition and basic of the model. This attitude is based on characteristics of evaluative correlation between modality (in range from "positive" to "negative") and intensity (in range from "strength" to "weakness") - see Fig. 1. The foundation of the instrument creation was a method of semantic differential.

Axis of the ordinates (Y) represents a characteristic of modality of judicial authority in perception of respondents. The mark "+" means here the strength of judicial authority. Another mark ("“-"), otherwise, means its weakness. Axis of abscissas (X) is a measure of people's attitude to activity of judicial authority. If this attitude is positive it is defined by mark "+", if it is negative another way - "“-“. Considering a suggested model in the context of the object of monitoring we may say that the extremum basis of this model may be presented as a Niccolò Machiavelli's tethis, which consist in follows:

Every government, having any communication with population, is found on the strength and harmony.

Due to using this system of coordinates it is possible to get more than just people's appraisal of judicial authority's activity, represented in

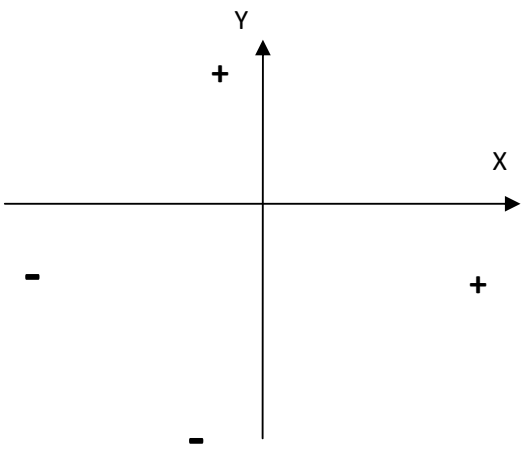

Fig. 1. Graphical presentation of "modality - intensity" model 
two terms - approval and rejection. It also helps to find out people's opinion about the strength and efficiency of judicial authority, its public reputation.

A proposed variant of model visualization also allow to research the results of monitoring in its development, in dynamics. For example, nowadays the result may be presented this way: people approve an activity of the judicial authority in general (their attitude may be described as positive), but they also consider that some drawbacks of the current system (like an absence of effective mechanism of sentences enforcement) make judicial authority weak. After a while people's attitude may be changed - they can start to admit a high reputation of the judicial authority, its strength and power, but the whole activity the authority does, may be, otherwise, described as unsatisfactory (so, people's attitude, in general, would be negative).

Besides, this model affords ground to examine population attitude to justice from the political and administrative point of view. It also allows to predict some changes, which may be critical for authorities in the future.

For analyzing some characteristics of justice and interpretation of results, we drew some distinctions between elements of the whole "judicial procedure" this way:

1. "Meeting" with a Court.

2. Litigation.

3. Judicial decision.

4. Enforcement of judicial decision.

Analogical way we had conceived and separated from each other some criteria of people's appraisal of courts' activity. The division was presented thus wise: attitude to the "meeting" with a Court, attitude to litigation, judicial decision and the last one to judicial decision's enforcement. Later there was defined a system of criteria, indicators and indexes, which would be capable to meet all the requirements and would be relevant to any model of monitoring.

\section{System of model criteria, indicators}

\section{A. Attitude to the «meeting» with a Court}

So-called "meeting with a Court" is defined within monitoring as a stage when the citizen for the first time within concrete legal proceedings encounter with a work of court.

As a matter of law it can be of various kinds options, depending on the status of the citizen in the concrete legal proceedings. So, the citizen can be a complainant - and then for him meeting with court corresponds to procedure of initiation of legal proceedings; can be a witness, than the meeting with court is a real arrival of person to court. Can be accused, the victim, the third party, come to process as the listener, etc. For all specified persons the meeting with court will have both special aspects, and some general moments.

As indicators as reference points for program preparation and questionnaire construction were allocated the following indicators, the most significant for each indicator:

- Whether is the property status of the person an obstacle at an appeal to the court - influence of the size of the state tax and other estimated court costs (including expenses on legal services and services of lawyers) on the decision to appeal to court was considered here.

- Politeness of the personnel of court, its participation in the solution of questions at the stage "meetings" - of course, the question here is not only about the stage "meetings" with court. Politeness as rather sensitive indicator is estimated and within further stages, but "initial" politeness in many respects defines the subsequent relation to court, in particular 
and therefore that further "meeting" procedure can not proceed.

- Clearness of procedures of an appeal to the court and predictability of further development of the relations with court a meeting as we described, can be different from the point of view of the one who and why meets. Perhaps, the initiator of process, can be the respondent, the defendant, it can be a witness, the visitor, etc. In this situation, to the person has to be all accompanying procedures are clear and for him there shouldn't be secret that will be farther after "meeting" took place. Without this understanding further normal interaction of the citizen and court is almost impossible and it significantly influences evaluation of the work of courts.

Results on all abovementioned indicators will be fixed on axis $\mathrm{X}$ in the scheme described above, that is to define positive/negative attitude of citizens directly to activity of the courts.

The indicator which we carry within this criterion to axis $\mathrm{Y}$ (force/weakness) sounds in a certain way:

- The relation to the status of court is one of the key indicators emphasizing authoritativeness of judiciary. It is used in abundantly researches, particularly in research VCIOM. For an assessment of this criterion, in particular, it is used questions why people go to court or don't go, whether will address in certain cases, etc.

\section{B. Attitude to litigation}

Criterion which unfold attitude of citizens to acquittal the main function by court - to hearing of cases. The case is about every procedure of consideration within any kind of legal proceedings. Besides, attitude to consideration of the case can be estimated by all citizens: those who was in process in any quality, and those who independently wasn't in process, but knows how cases in court are considered, from any sources (from relatives, friends, acquaintances, from telecasts, mass media, etc.).

For disclosure of the specified criterion, proceeding from requirements which were described above, we allocated the following indicators.

- Openness and transparency of judicial proceedings Publicity of judicial proceedings. Judicial proceedings are open and transparent for public are the indicator acting as the basic in a number of domestic and foreign researches. In our opinion, the specified indicator reveals through the following indicators:

- trial participants are informed on stages of judicial proceedings and that has to occur at the end, the court adequately explains the arisen questions of the meeting course;

- trial participants can represent the arguments, requirements, objections and proofs;

- trial participants can comment in essence on arguments, requirements, objections and the evidence produced by other participants;

- everybody can pass without excessive obstacles and attend a judgement hall;

- Mass media can attend a judgement hall and fix the events.

About knowledge and attitude of this is necessary to formulate questions for respondents.

- Independence of court - this indicator is carried by us for display on axis $\mathrm{Y}$, that is for determination of force or weakness of judiciary. Independence in this context means that the judge doesn't concede to 
any external influence. In this aspect we are interested in representation of citizens about the volume of external influence on court. The question of independence is one of the main question of the domestic and foreign researches described above. For the state it is one of the most important indicators characterizing the level of trust of citizens to judiciary.

- Impartiality of court - this indicator means that the judge is impartial, doesn't express preference to any of trial participants in any way. The judge doesn't determine the decision from citizen's perspective.

- Speed of consideration of the case - one of the most sensitive moments for the population. It follows including from among addresses from the Russian Federation to the European Court of Human Rights with complaints to too slow consideration of the case. Besides, it is necessary to pay attention to the last serious changes of the legislation concerning increase in procedural terms of trial, and also providing compensations to citizens for violation by citizens of this term.

\section{Attitude to judicial decision}

The judicial decision as the special phenomenon demands a separate assessment.

Sensitivity of the population to this criterion is rather high owing to what the judicial decision is associated at citizens with means of restoration of the violated rights (legitimate interests).

In our opinion, this criterion reveals through the following indicators:

- Clearness of judicial decision

- Legality and justice of judicial decision

- Authoritativeness of judicial decision
The last indicator is carried by us for display to axes $\mathrm{Y}$, that is determining force or weakness of judiciary, the others - on axis $\mathrm{X}$.

\section{Attitude to judicial decision's enforcement}

As the criterion for the instrument of monitoring of judicial activity can raise doubts from those positions that enforcement of judicial decisions formally in the Russian Federation doesn't depend on courts, compulsory enforcement of judicial decisions is assigned to enforcement jurisdiction.

Nevertheless, we consider necessary to include this criterion in group of criteria on two bases.

First, objectively restoration of the rights and freedoms, protection of the legitimate interests making a justice essence can't be presented without execution of judgments. After all it is obvious that unsatisfied judgement is equivalent to not restored right or the unprotected interest. In other words, feasibility of judgments is an essential sign of justice without which judicial protection turns into illusion.

Secondly, execution or non-execution of the judgment is usually attributed by the person with that who took out it, i.e. with court and its activity. In this regard, the specified criterion directly belongs to identification of the relation of the citizen to work of judicial system. Thus, without forgetting about the requirement of economy, we open this criterion via two indicators: feasibility and speed of execution.

Schematically model which we check, having supplied each construct (criterion) with "its" indicators looks as follows:

The relation to activity of court, it is the relation, first of all, of positive / negative attitude to court and perception of strong / weak court.

For this reason we tried to find sufficient number of indicators and to independent ("activity 


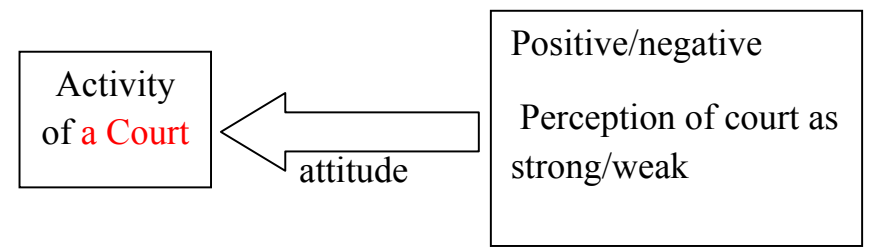

Fig. .2 Attitude to activity of a Court

of court"), and to dependent ("modality" and "force/weakness") to variables.

When developing the concept "activity of court" for questionnaire, the high importance not only real main activity components, but also common cultural knowledge of the person of court and trials and conditions of implementation of activity, steady interest in the corresponding messages in mass media was established.

At a choice of indicators for a dependent variable possible distinctions in the range and intensity of the relation to activity of court expressed by respondents were considered.

\section{Methods}

Methods for population-based surveys were offline and online. This was the main tool where semantic differential scale was. Semantic differential scale was used by us to assess the activity indicator court in terms of strength / weakness. Detailed analysis procedures semantic scaling beyond the scope of this work. Here we only note that the general approach allows respondents to evaluate multiple objects on the scales each of which is defined in the sense of a pair of opposite adjectives (antonyms).

Modeling criteria we laid the basis for meaningful survey items. Clarity scheme survey gave us practical guidelines for the selection of survey items. The questionnaire included, firstly, the questions to measure the dependent variables, and, secondly, all the explanatory independent variables which have also been translated into the language of the relevant issues. Third, we have identified issues relating to the possible control variables and standard "passport" issues such as gender, age, occupation, education, marital status and others.

The choice between the judgments suggests that the respondent chooses that judgment, which reflects the extent of his benevolence towards the object. Orderliness judgments along some "installation" of the continuum is usually obvious and for the researcher, and for most respondents.

To illustrate,

"In your opinion, the procedure of going to court is difficult?"

$\begin{array}{cccccccc}-3 & -2 & -1 & 0 & 1 & 2 & 3 \\ \text { Complex } & & & & & \text { Light }\end{array}$

In this way, our questionnaire consisted of executed instructions in the text, the content and passports.

In the instructions, in the introduction to the questionnaire contains information about the purpose of research, on who is conducting the survey, the assurances of confidentiality (anonymity). Due to the fact that the practice of the survey showed that excessively long and detailed introductions do not lead to any significant improvement in the quality of the responses or increase motivation to cooperate, then the owner has developed a concise view.

The questionnaire defined fields and spacing issues (or blocks of questions). Each position has a pre-assigned response numeric code, which we 
in the instructions and asked the respondent circle the appropriate numbers circled.

Part of the questions concerns the performance conditions of the court in the questionnaire. The basic set of questions reflects our business model ships. Also presented filter questions (or "on-off" questions) that allow a selected group of respondents answering (by virtue of their status, experience, interest or knowledge) on dependent questions.

The order of questions in the questionnaire was defined as follows:

1) A simple open-ended question on the association and the perception of the court.

2) Then, simply factual issues on which the respondent can easily and quickly respond.

3) Next, questions are grouped into semantic blocks.

4) In the content blocks presented little tips and specific instructions on how to fill for a clear understanding of the problem.

Then we conducted a pilot study in the Krasnoyarsk Territory. Respondents were adult citizens. At this stage, we tested the suitability of the questionnaire method for obtaining primary information. We are testing the system research procedures in general, the organization of mass data collection and sampling scheme.

The sample for aerobatics was small. Different respondents (gender, age, education, social status, etc.) participated in the study. This gave the opportunity to test the questionnaire in terms of accounting for all social differences, detect ambiguities issues that uniquely understand people with different education, ethnicity and social status.

\section{Approbation of the instrument and deliberation of the results}

The instrument of evaluation of availability of justice was piloted in natural conditions, in other words, in the field campaign.
On the field investigation phase we conduct survey in the towns and townships of Krasnoyarsk Territory. Moreover, online surveys were used by the means of the Internet, e-mail, websites www. ippd.ru and http://krasn.pravo.ru/ and direct e-mail.

Low cost, automatism of information processing (all information, received from the surveys, automatically files to the database) and informality of feedback with respondents are absolute advantages of this instrument.

The main disadvantages: impossibility of compliance with the requirements of representativeness, minimization of verifiability of information, unavailability for those social groups, who do not use the Internet.

\section{A. Participants}

Presupposition, that each legally capable person upward eighteen years old has a decided opinion (overview) about a court, its activity, justice etc. and on this ground is a potential respondent, was introduced.

For the purpose of providing of representativeness investigative sample was formed in the light of specific settled features of Krasnoyarsk Territory: allocation of large regional centers and rural settlements.

We also used non-random sample which is basically selection (purposeful, target-oriented, choice at the discretion) using the method of typical representatives.

With the use of this method we picked up the units of general population, having the mean observation of the characteristic.

In the issuance the sample of the research was designed by Krasnoyarsk Territory citizens, involving in litigation or not. The survey was conducted in Krasnoyarsk, five regional centers and four rural settlements of Krasnoyarsk Territory. In total there were 1200 respondents to the survey (180 of which gave a reply in the online mode). 


\section{B. Deliberation}

Received primary data was analyzed by us from the standpoint of the developed model, where two factors of relations were pointed as evaluation of the court's activity by the citizens:

F1 (the first factor) - "Modality" of the relation. At this point we took into account positive and negative respondents' assessments.

F2 (the second factor) - "Strengthweakness". Here we took into account those relations between citizens which characterize activity in the view of strong or weak positions of court's activity.

Both factors are bipolar, in other words, they are defined in opposition.

Received primary data was treated with the use of the method of factor analysis. In the table № 1 the data, demonstrating the placement of respondents along the axis, who somehow meet with the court (involving in litigation or just getting legal advice in the hall of justice) or never deal with the court, is presented.
Further, on the Fig. 3, the placement of the answers of respondents dealing with the court (involving in litigation or being in the court-house) and never dealing with the court, is shown.

In such a way we ascertain that attitude of citizens to the court is vastly differentiated and depends on presence or lack of experience of interaction with courts.

Citizens, who do not attend the court, estimate positively and in a greater degree define justice as strong.

Citizens, who were involved in litigation, have negative point of view onto courts' activities and define justice as weak.

\section{Conclusion}

The research work gives us an option to ascertain that evaluations of court's activity by different groups of citizens essentially differ. Those citizens, who anyhow deal with the activity of the courts, relate to the courts rather negatively, than those, who have a notion about courts from any sources of information.

Table 1. The placement of respondents, facing with the court and not, along the axis of factors F1 and F2.

\begin{tabular}{|c|c|c|}
\hline & Modality & Strength \\
\hline Face & $-14,45$ & $-19,2$ \\
\hline Do not face & 17,2 & 5,5 \\
\hline
\end{tabular}

\section{Attitude to the court's activity}

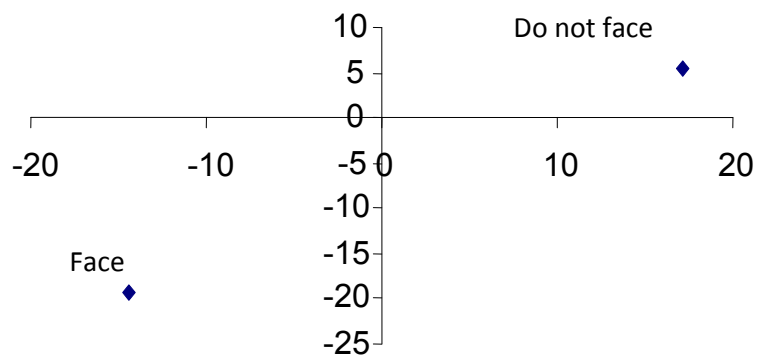

Fig. 3. Graphical allocation of attitudes to the court's activity 
Received data allows over the regular gathering of information to fix the tendencies and changes in public attitude to courts' activities and to monitor the situation of administration of justice in our country.

Executed work and developed model of monitoring of justice give us an opportunity, firstly, to evaluate the effectiveness of justice as the main mechanism of legal protection with account of Russian specificity and as an instrument of problem determination in judicial system, secondly, to monitor the situation and to disclose the problematics and points, required for increase of efforts taking by the government and civil society for rising of availability and quality of justice.

At the same time we understand that the proposed model of the monitoring of justice as much as other products of the culture is not absolute and is in need of critical re-evaluation.

\footnotetext{
The Project No. KF-74 'Monitoring of quality of justice in system of justice of the peace: the regional model”, 1 June - 30 November 2010.
}

\title{
Мониторинг правосудия
}

\section{(в аспекте отношения населения) как инструмент управления}

\author{
Н.Г. Стойко ${ }^{a}$, Л.А. Новопашина ${ }^{\sigma}$, А.А. Петров ${ }^{6}$ \\ ${ }^{a}$ Санкт-Петербургский государственный университет \\ Россия, 199026, Санкт-Петербург, Васильевский остров, 22-я линия, 7 \\ Сибирский федеральный университет \\ Россия, 660041, Красноярск, пр. Свободный, 79
}

\begin{abstract}
В статье предложена модель мониторинга правосудия, которая может быть использована для оиенки его эффективности. Результаты проведенного исследования, основанного на предложенной модели, демонстрируют разнииу в отношении граждан к публичному правосудию в зависимости от опыта взаимодействия с судебной системой. Предлагаемый инструмент может быть использован для мониторинга общественного отношения $\kappa$ деятельности судов и восприятия доступности и качества правосудия.
\end{abstract}

Ключевые слова: мониторинг, управление, доступное и качественное правосудие, критерии и индикаторы, модель мониторинга правосудия.

Научная спеииальность: 19.00.00 - психологические науки. 